\title{
Chemical composition and fatty acid profile in meat from grazing lamb diets supplemented with ryegrass hay, fishmeal and soya bean meal as PUFA sources
}

\author{
Jose Romero-Bernal ${ }^{1}$ Ernesto Morales Almaraz ${ }^{1}$ Octavio Alonso Castelán Ortega $^{1}$ \\ Nazario Pescador Salas ${ }^{1}$ Manuel González-Ronquillo ${ }^{*}$
}

\footnotetext{
${ }^{1}$ Departamento de Nutrición Animal, Facultad de Medicina Veterinaria y Zootecnia, Universidad Autónoma del Estado de México, Instituto Literario, 100 Ote, 50000, Toluca, Estado de México, México. E-mail: mrg@uaemex.mx. Corresponding author*.
}

\begin{abstract}
This study examined the characteristics of the fatty acids profile in the meat of lambs fed grazing and supplemented with different PUFA sources. Thirty Suffolk lambs were used $(37.2 \pm 5.4 \mathrm{~kg} \mathrm{BW})$, grazing on perennial ryegrass (Lolium perenne) (12h $\left.d^{-1}\right)$ and supplemented $\left(30 \mathrm{~g} \mathrm{~kg}^{-1} \mathrm{~B} W^{0.75}\right)$ with ryegrass hay $(R G H)$, or supplements formulated with fishmeal (FHM) or soybean meal (SBM). Lambs were used in a completely randomized design. Results showed an effect on total SFA, with SBM higher than RGH (P=0.033), and SBM and FHM showing higher MUFA content compared with RGH (P=0.001). Total PUFA content was higher for RGH, followed by FHM and with the lowest content for SBM $(P=0.001)$. Concluding that there is a variation in fatty acid content depending on the lipid-protein source used in supplementation in grazing sheep, the content of PUFA was higher for grazing lambs supplemented with RGH compared with those supplemented with FHM or SBM.
\end{abstract}

Key words: lambs, grazing, fatty acids, meat, PUFA.

Perfil de ácidos graxos na carne ovina suplementado com farinha de peixe ou farinha de soja

RESUMO: Este estudo analisou as características dos ácidos graxos na carne de cordeiros alimentados com pastagem e suplementados com diferentes fontes de proteina. Trinta cordeiros Suffolk foram utilizados (37,2 $55,4 \mathrm{~kg}$ BW) que pastavam em azevém perene (Lolium perenne) $\left(12 \mathrm{~h} \mathrm{~d}^{-1}\right)$ e suplementados com $\left(30 \mathrm{~g} \mathrm{~kg}^{-1} \mathrm{PV}^{0,75}\right)$ com azevém feno (RGH), ou concentrados formulado com farinha de peixe (FSM) ou farelo de soja (SBM). Os resultados mostram um efeito sobre o total SFA, sendo mais elevada do que SBM RGH $(P=0,033)$. SBM e FSM mostrando o maior teor total de MUFA vs. RGH (P=0,001). O teor total de AGPI foi maior para $R G H>E F M>S B M(P=0,001)$. Concluindo que há uma variação no teor de ácidos graxos dependendo da fonte de proteina utilizada na suplementação emanimais pastoreados, o teor de PUFA foi maior para ovinos mantidos em comparação com os suplementado com EFM ou SBM.

Palavras-chave: cordeiros, pastagem, ácidos graxos, carne.

\section{INTRODUCTION}

Meat consumers are influenced by a series of factors such as alimentary security, health, environmental impact and animal welfare (GRUNERT et al., 2004). It is believed that meat of sheep produced on pasture has a superior nutritional quality and better taste (SERRANO et al., 2007). Moreover, the specific components of the diet might directly affect the quality of the meat if they are transferred to it (VASTA \& PRIOLO, 2006). Previous research has shown that including grass in the diet increases conjugated linoleic acid (CLA) concentration in intramuscular fat of ruminants (FRENCH et al., 2003). Polyunsaturated fatty acids (PUFAs) are not only essential nutrients for humans, but also significant in providing protection from cardiovascular diseases, inflammatory diseases, diabetes, some cancers and behavioral disorders (PARK, 2009). Greater fat content is generally found in muscle from animals raised on concentrate compared with animals allowed to graze herbage at pasture (HAJJI et al., 2016).

The objective of the present study was to evaluate chemical composition and fatty 
acid content in the meat of Suffolk lambs fed in an intensive grazing system supplemented with different PUFA sources.

\section{MATERIALS AND METHODS}

Prairie and ryegrass hay procedure

A prairie of $120 \times 100 \mathrm{~m}$ composed of $81 \%$ perennial ryegrass (Lolium perenne), 12\% clover (Trifolium repens) and 7\% weeds was divided into strips $(4 \times 100 \mathrm{~m})$ in a rotational grazing system whereby one strip was grazed for one day, then rested for 30 days - with animals grazing for a period of $70 \pm 7 \mathrm{~d}$. Prior to the beginning of the experiment the prairie was mowed and hayed, and the excess forage of the prairie where the lambs were not grazing was cut ( $5 \mathrm{~cm}$ from the ground) and hayed (RGH) and the latter used as supplement.

\section{Animals and diets}

The experiment began with thirty male growing Suffolk lambs $(37.2 \pm 5.4 \mathrm{~kg} \mathrm{LW})$, which were assigned to three treatments (10 animals per treatment), with all the animals grazing perennial ryegrass (Lolium perenne) $12 \mathrm{~h} / \mathrm{d}$ ad libitum (0700 to $1900 \mathrm{~h}$ ), and supplemented in individual pens before $(0700 \mathrm{~h})$ and after grazing $(2000 \mathrm{~h})$ as follows: treatment one was supplemented with RGH, $378 \pm 65 \mathrm{~g} \mathrm{DM} \mathrm{d}^{-1}$ and $0.84 \mathrm{~g} \mathrm{~kg}^{-1} \mathrm{LW} \mathrm{d}^{-1}$ of mineralvitamin supplement (Multitec, Malta Clayton ${ }^{\circledR}$ ); treatment two was supplemented with fishmeal (FHM) treatment, (30 $\mathrm{g} \mathrm{kg}^{-1} \mathrm{BW}^{0.75}$ supplement), based on $17.6 \%$ fishmeal, $29.4 \%$ rapeseed meal, $50 \%$ corn grain, and $3 \%$ vitamins and minerals); and treatment three was supplemented with soybean meal diet (SBM), (30 $\mathrm{g} \mathrm{kg}^{-1} \mathrm{BW}^{0.75}$ supplement), based on $17.6 \%$ hydrolyzed soybean meal, $26.4 \%$ soybean meal, $53 \%$ corn grain, and $3 \%$ vitamins and minerals) (Table 1). Animals had access to water ad libitum. Lambs management and all procedures in the present study were performed according to the Animal Experimental Guidelines of the Universidad Autonoma del Estado de Mexico.

\section{Meat samples}

All the animals were slaughtered when they reached $50 \mathrm{~kg} \mathrm{LW}$. Lambs were slaughtered after 12 hours of fasting; the Longissimus dorsi $\left(6^{\text {th }}\right.$ to $13^{\text {th }}$ ribs) from the left side of the carcass after $24 \mathrm{~h}$ post mortem were taken and vacuum-packed at $20^{\circ} \mathrm{C}$ for later analyses. Meat samples were defrosted at the end of a 20-day period, due to the animals having been slaughtered at different times.

\section{Chemical analysis}

Feed samples were analyzed for DM (\#934.01), ash (\#942.05), $\mathrm{N}(\# 954.01)$ and $\mathrm{EE}$ (\#920.39) according to AOAC (2000). The neutral detergent fiber (NDFom, Van SOEST et al., 1991), acid detergent fiber (ADFom) and lignin (\#973.18) (AOAC, 2000) were analyzed using an ANKOM200 Fiber Analyzer Unit (ANKOM Technology Corporation, Macedon, NY, USA). NDFom was assayed without use of an alpha amylase but with sodium sulfite in the NDFom. Both NDFom and ADFom were expressed without residual ash.

Meat samples were defrosted $\left(24 \mathrm{~h}, 4^{\circ} \mathrm{C}\right)$ and analyzed for moisture (g water $100 \mathrm{~g}^{-1}$ sample), ash, protein $(\mathrm{N} \times 6.25)$ and intramuscular fat according to AOAC (1990).

\section{Fatty acids determination}

The Longissimus dorsi muscle was thawed $\left(24 \mathrm{~h}, 4^{\circ} \mathrm{C}\right)$ and analyzed for fatty acids (FA); lipids were extracted according to AOAC Method 982.23 (2000), before fatty acids were determined. The FA were transmethylated according to MORRISON \& SMITH (1964), and the FA profile was obtained by a gas chromatograph (HP-689011) equipped with a flame ionizer detector, by injecting a $1 \mu 1$ sample with a capillary column DB-5 (100m x $0.25 \mathrm{~mm} \times 0.2 \mu \mathrm{m})$. As a reference for fatty acids we used a standard (Kit No. 61 CXMeti esters of fatty acid, poly Science Corporation, Chemical division. Sigma Aldrich) that identified C10:0, C12:0, C14:0, C16:0, C18:0, $\mathrm{C} 18: 1, \mathrm{C} 18: 2$ and $\mathrm{C} 20: 0$.

\section{Calculus and statistical analysis}

The saturated fatty acids (SFAs), monounsaturated fatty acids (MUFAs) and polyunsaturated fatty acids (PUFAs) in meat fat were calculated using the following equations:

$$
\begin{aligned}
& \text { SFA }=\text { C12:0 }+ \text { C14:0 + C16:0 + C18:0 + C:20:0 } \\
& \text { MUFA = C18:1n- } 9 \\
& \text { PUFA = C18:2n-6 }
\end{aligned}
$$

The chemical composition of the meat and fatty acid profiles were analyzed by means of a completely randomized design, $\mathrm{y}_{\mathrm{ij}}=\mu+\mathrm{Tx}_{\mathrm{i}}$ $+\varepsilon_{\mathrm{ij}}$, where $\mathrm{y}_{\mathrm{ij}}=$ response variable; $\mu=$ general mean; $\mathrm{Tx}_{\mathrm{i}}=$ effect of the treatment factor; and $\varepsilon_{\mathrm{ij}}$ $=$ experimental error. An analysis by contrasts was carried out C1) RGH vs. FHM and SBM and C2) FHM vs. SBM treatments (STEEL et al., 1997) using the statistical program SPSS version 13, GEORGE \& MALLERY (2006). 
Table 1 - Formulation, chemical composition (g/kg DM), and fatty acid composition in grazing lambs supplemented with RGH, SBM or FHM $\left(20 \mathrm{~g} \mathrm{~kg}^{-1} \mathrm{LW}^{0.75}\right)$.

\begin{tabular}{|c|c|c|c|c|}
\hline \multirow[b]{2}{*}{ Item } & \multirow{2}{*}{$\begin{array}{c}\text { Basal diet } \\
\text { Prairie }^{\mathrm{a}}\end{array}$} & \multicolumn{3}{|c|}{ 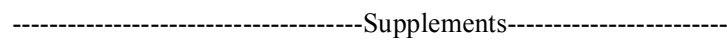 } \\
\hline & & $\mathrm{RGH}$ & FHM & SBM \\
\hline Ryegrass hay & & 970 & 0 & 0 \\
\hline Fish meal & & 0 & 176 & 0 \\
\hline Soybean meal Hi-pro & & 0 & 0 & 176 \\
\hline Soybean meal & & 0 & 0 & 264 \\
\hline Rapeseed meal & & 0 & 294 & 0 \\
\hline Corn grain & & 0 & 500 & 530 \\
\hline Minerals & & 30 & 30 & 30 \\
\hline \multicolumn{5}{|c|}{ - Chemical composition, $\mathrm{g} \mathrm{kg}^{-1} \mathrm{DM}-\mathrm{-}$} \\
\hline $\mathrm{DM}$ & 123 & 875 & 911 & 903 \\
\hline $\mathrm{OM}$ & 901 & 906 & 940 & 934 \\
\hline $\mathrm{CP}$ & 201 & 195 & 258 & 248 \\
\hline FAT & 33 & 30 & 22 & 9 \\
\hline $\mathrm{NDF}$ & 550 & 537 & 148 & 195 \\
\hline $\mathrm{ADF}$ & 269 & 247 & 58 & 32 \\
\hline Lignin & 29 & 27 & 48 & 44 \\
\hline $\mathrm{ME}, \mathrm{MJ} \mathrm{kg}^{-1 \mathrm{~b}}$ & 8.5 & 8.5 & 12.8 & 13.5 \\
\hline \multicolumn{5}{|c|}{ 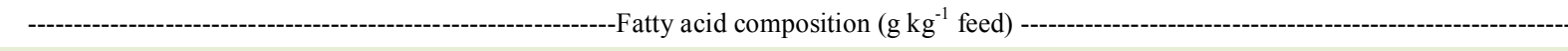 } \\
\hline C16:0 & 7.0 & 3.8 & 3.1 & 1.2 \\
\hline C18:0 & 1.8 & 0.5 & 0.8 & 0.3 \\
\hline C18:1 n-9 & 3.7 & 0.5 & 4.7 & 1.6 \\
\hline C18:2 n-6 & 4.8 & 4.2 & 5.8 & 4.1 \\
\hline C18:3 n-3 & 9.8 & 21.0 & 3.3 & 0.5 \\
\hline $\mathrm{SFA}^{\mathrm{c}}$ & 8.1 & 4.4 & 3.9 & 1.5 \\
\hline USFA $^{\mathrm{d}}$ & 18.2 & 25.7 & 13.7 & 6.2 \\
\hline MUFA $^{\mathrm{e}}$ & 3.7 & 0.5 & 4.7 & 1.6 \\
\hline PUFA $^{\mathrm{f}}$ & 14.5 & 25.2 & 9.0 & 4.6 \\
\hline
\end{tabular}

${ }^{\mathrm{a}}$ Prairie diet $=$ basal diet, $\mathrm{RGH}=$ Rye grass hay diet, $\mathrm{FHM}=$ fish meal diet, SBM = Soya Bean Meal diet. Vitamin and mineral mixture provided by Malta Clayton $\left(\right.$ Multitec ${ }^{(\mathbb{})}$ ). ${ }^{\mathrm{b}}$ Calculated. ${ }^{\mathrm{c}} \mathrm{SFA}$ ( saturated fatty acids) $=\mathrm{C} 16: 0+\mathrm{C} 18: 0 .{ }^{\mathrm{d}} \mathrm{UFA}$ (unsaturated fatty acids) $=\mathrm{C} 16: 1$, $\mathrm{C} 18: 1 \mathrm{n}-9+\mathrm{C} 18: 2 \mathrm{n}-6+\mathrm{C} 18: 3 \mathrm{n}-3 .{ }^{\mathrm{e}}$ MUFA (monounsaturated fatty acids) $=\mathrm{C} 16: 1+\mathrm{C} 18: 1 \mathrm{n}-9 .{ }^{\mathrm{f}} \mathrm{PUFA}$ (polyunsaturated fatty acids $)=\mathrm{C} 18: 2 \mathrm{n}-6+\mathrm{C} 18: 3 \mathrm{n}-3$.

\section{RESULTS AND DISCUSSION}

\section{Chemical composition}

There were no differences $(\mathrm{P}>0.05)$ for moisture and protein in the meat (Table 2). The difference in fat content in the meat of lambs raised on concentrates compared with lambs allowed to graze herbage at pasture was significant $(\mathrm{P}<0.05)$. Meat fat content was higher $(\mathrm{P}=0.001)$ for $\mathrm{FHM}$ compared with RGH and SBM diets. The moisture content of the meat was similar to that found by HAJJI et al. (2016); moisture, protein and lipid content were similar to BEZERRA et al. (2016). The slight differences may be due to several factors, among them the breed (HAJJI et al., 2016) and the age of the animals, which could influence the amount of fat deposition when the animals are supplemented with concentrate or fed in a pasture system (KARACA et al., 2016). The moisture content was lower than KARACA et al. (2016) and 
Table 2 - Chemical composition (g $100 \mathrm{~g}^{-1}$ wet tissue) in the Longissimus dorsi muscle of grazing lambs supplemented with rye grass hay (RGH), fish meal (FHM) and soybean meal (SBM).

\begin{tabular}{lccccccc}
\hline & & & & & & & \\
& & & & & \\
Characteristic & RGH & FHM & SBM & SEM & Tx & C1 \\
Moisture & 68.3 & 65.0 & 63.8 & 1.14 & 0.473 & 0.246 \\
Protein & 20.3 & 21.6 & 23.5 & 2.48 & 0.534 & 0.447 & 0.749 \\
Fat content & $2.38^{\mathrm{b}}$ & $3.37^{\mathrm{a}}$ & $2.66^{\mathrm{b}}$ & 0.11 & 0.001 & 0.167 & 0.001 \\
Ash & 1.23 & 1.24 & 1.19 & 0.09 & 0.426 & 0.376 \\
\hline
\end{tabular}

${ }^{\text {ab }}$ Values in files with different letters are significantly different $(\mathrm{P}<0.05)$. SEM, Standard Error Mean. Contrast: C1) RGH vs. FHM and SBM; C2) FHM vs. SBM.

the protein and fat content were similar to when the animals were supplemented with FHM and SBM.

\section{Meat fatty acids content}

The variation in the FA profile (Table 3) depends on the type of lipid source offered (ZERVAS \& TSIPLAKOU, 2011). This calculation was conducted for the principal fatty acids C16:0, C18:0, C18:1, C18:2 and C18:3, excluding C20:0. Amounts of $\mathrm{C} 10: 0, \mathrm{C} 12: 0, \mathrm{C} 14: 0$ and $\mathrm{C} 18: 2$ were higher ( $\mathrm{P}=0.001)$ for $\mathrm{RGH}$ compared with $\mathrm{SBM}$ and FHM diets; $\mathrm{C} 16: 0$ and $\mathrm{C} 18: 0$ were lower $(\mathrm{P}=0.001)$ in $\mathrm{RGH}$ than FHM and SBM, which was reflected in low $(\mathrm{P}=0.033)$ content of total SFA in $\mathrm{RGH}$. The major fatty acid identified in this study was $\mathrm{C} 18: 1$, which was higher ( $\mathrm{P}=0.001)$ for SBM and FHM; in contrast, $\mathrm{C} 18: 2$ was higher $(\mathrm{P}=0.001)$ in $\mathrm{RGH}$ followed by FHM and SBM. Total MUFA was higher $(\mathrm{P}=0.001)$ for FHM and SBM compared with RGH; whereas, the highest content of PUFA was for RGH treatment, followed by FHM, and the lowest for SBM treatment. The ratio PUFA/SFA was higher $(\mathrm{P}<0.001)$ for $\mathrm{RGH}$ followed by FHM and SBM treatments.

The differences in the content of short and medium chain FA in Longissimus dorsi muscle as a result of supplementation are not consistent with the observations of PONNAMPALAM et al. (2001), who found no difference in the concentration of medium chain FA (C14:0, C16:0) and C18:0 in Longissimus dorsi of sheep fed with FHM or SBM supplements. On the contrary, and in line with our results, KARACA et al. (2016) observed higher concentrations of C18:2 when the animals were fed with pasture. Linoleic acid present in the tissue derives entirely from its presence in the diet; this fatty acid is particularly abundant in food concentrates (grains and oil seeds), and is degraded to monounsaturated and saturated FA in ruminants by the process of rumen microbial biohydrogenation, with only a small proportion, around 10\% compared to the amount ingested with the diet, being available for incorporation into tissue lipids (WOOD et al., 2008). The lowest concentration of C18:2 in FHM and SBM may have been related to favorable conditions for extensive ruminal hydrogenation in the rumen, in the process generating high levels of MUFA and SFA (C18:1 and C18:0, respectively), promoting their absorption and deposition in tissue. In fact, both C18:1 and C18:0 showed high concentration in FHM and SBM compared with RGH (Table 3). In this sense ZERVAS \& TSIPLAKOU (2011) confirmed that the lipid composition of the meat reflects the metabolism of lipids in the rumen. PONNAMPALAM et al. (2001) reported lower content of C18:2 in the muscle Longissimus dorsi of sheep whose diets were supplemented with FHM compared with a control diet based on oat straw and alfalfa hay (80:20), or supplemented with rapeseed or SBM. In contrast, RADUNZ et al. (2009), supplementing PUFA sources in lamb diets, reported similar results to the present study, showing higher concentration of PUFA in meat lambs. Supplementation with soybean or FSH as a source of PUFA in lamb finishing diets had only modest effects on fatty acid composition of muscle and adipose tissues. Similar studies have come to the same conclusion based on the effects of using unsaturated oil supplementation in high-concentrate diets in beef (ENGLE et al., 2000; BEAULIEU et al., 2002) and lambs (RADUNZ et al., 2009). Although differences in meat FA composition might be a result of changes which take place in the rumen, a confounding effect of variable intramuscular FA metabolism, as suggested by the desaturation and elongation of FA, cannot be excluded. The highest concentration of C18:1 in meat observed in this study is consistent with that reported by other authors evaluating diets with different types of concentrate (KARACA et al., 2016; DEMIREL 
Table 3 - Fatty acids composition (percentage of total fatty acids) of intramuscular fat (m. Longissimus dorsi) from lambs fed with grass supplemented with rye grass hay (RGH), fish meal (FHM) and soybean meal (SBM) as PUFA sources.

\begin{tabular}{|c|c|c|c|c|c|c|c|}
\hline \multirow[t]{2}{*}{ Fatty acid } & \multicolumn{4}{|c|}{ 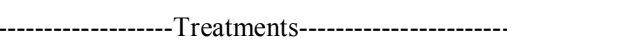 } & \multicolumn{3}{|c|}{--P value-------- } \\
\hline & $\mathrm{RGH}$ & FHM & SBM & SEM & $T x$ & $\mathrm{C} 1$ & $\mathrm{C} 2$ \\
\hline C10:0, capric & $0.29^{\mathrm{a}}$ & $0.12^{\mathrm{c}}$ & $0.19^{\mathrm{b}}$ & 0.01 & 0.001 & 0.197 & 0.001 \\
\hline $\mathrm{C} 12: 0$, lauric & $0.33^{\mathrm{a}}$ & $0.11^{\mathrm{b}}$ & $0.18^{\mathrm{b}}$ & 0.02 & 0.001 & 0.001 & 0.022 \\
\hline C14:0, myristic & $5.20^{\mathrm{a}}$ & $2.77^{\mathrm{c}}$ & $3.89^{\mathrm{b}}$ & 0.12 & 0.001 & 0.001 & 0.001 \\
\hline C16:0, palmitic & $25.12^{\mathrm{b}}$ & $27.28^{\mathrm{a}}$ & $27.32^{\mathrm{a}}$ & 0.38 & 0.001 & 0.003 & 0.945 \\
\hline C18:0, stearic & $19.36^{\mathrm{b}}$ & $21.86^{\mathrm{a}}$ & $21.18^{\mathrm{a}}$ & 0.38 & 0.001 & 0.004 & 0.225 \\
\hline C18:1 n-9 oleic & $42.01^{\mathrm{a}}$ & $44.98^{b}$ & $45.43^{b}$ & 0.57 & 0.001 & 0.004 & 0.585 \\
\hline C18:2, n-6 linoleic & $7.45^{\mathrm{a}}$ & $2.57^{\mathrm{b}}$ & $1.55^{\mathrm{c}}$ & 0.15 & 0.001 & 0.001 & 0.001 \\
\hline C20:0, n-6 arachidic & 0.12 & 0.15 & 0.14 & 0.01 & 0.164 & 0.066 & 0.633 \\
\hline Total SFA & $50.52^{b}$ & $52.43^{\mathrm{ab}}$ & $53.00^{\mathrm{a}}$ & 0.62 & 0.033 & 0.064 & 0.047 \\
\hline Total MUFA & $42.01^{\mathrm{b}}$ & $44.98^{\mathrm{a}}$ & $45.43^{\mathrm{a}}$ & 0.06 & 0.001 & 0.004 & 0.581 \\
\hline Total PUFA & $7.45^{\mathrm{a}}$ & $2.57^{\mathrm{b}}$ & $1.55^{\mathrm{c}}$ & 0.15 & 0.001 & 0.001 & 0.001 \\
\hline MUFA/SFA & 0.83 & 0.85 & 0.86 & 0.02 & 0.618 & 0.335 & 0.956 \\
\hline PUFA/SFA & $0.14^{\mathrm{a}}$ & $0.05^{\mathrm{b}}$ & $0.03^{\mathrm{c}}$ & 0.004 & 0.001 & 0.001 & 0.003 \\
\hline
\end{tabular}

SFA: saturated fatty acids; MUFA: monounsaturated fatty acids; PUFA: polyunsaturated fatty acids. ${ }^{\text {abc }}$ Values in rows with different letters are significantly different $(P<0.05)$. SEM, Standard Error Mean. Contrast: C1) RGH vs. FHM and SBM; C2) FHM vs. SBM.

et al., 2004). The concentration of $\mathrm{C} 18: 1$ in the meat supplemented with RGH could be related to increased activity of the enzyme Co-A desaturase steryl, the main lipogenic enzyme, which produces C18:1 from C18:0.

The fatty acids found in greater proportion in the lamb fat meat were oleic (44.1\%), palmitic $(26.5 \%)$ and stearic $(20.8 \%)$ fatty acids (Table 3 ). Fatty acid profile was influenced by the PUFA supplement $(\mathrm{P}<0.05)$, a finding similar to that of BEZERRA et al. (2016).

According to MOLONEY et al. (2001), myristic acid (14:0) and palmitic acid (16:0) are considered to be hypercholesterolemic fatty acids and thereby increase the synthesis of cholesterol, promoting the accumulation of low-density lipoprotein, which is a risk factor for cardiovascular diseases. According to FRENCH et al. (2003), C14:0 is the most undesirable fatty acid; however, according to the reported content, the effect of myristic acid on lamb meat does not imply high cholesterol levels when compared with the rest of the fatty acids profile, but the level of C14:0 was higher than that reported by BEZERRA et al. (2016).

The percentage of SFA in intramuscular fat was higher in RGH lambs than SBM supplemented $(\mathrm{P}=0.033)$; these values are similar to those reported by KARACA et al. (2016), where the animals fed with pasture had higher SFA than those fed with concentrate.
Conversely PUFAs, with lower blood cholesterol concentrations, are often present at low levels in meat, especially those of the n-3 series, which have particularly beneficial effects on health. In this sense, they can be used to manipulate the FA content of muscle to improve nutritional balance, i.e. increasing the ratio PUFA:SFA. In the present study, the better ratio PUFA/ SFA in fat meat was observed in sheep supplemented with RGH compared with FHM, followed by SBM. These levels are below the recommendation for human diet, which is 0.45 (HMSO, 1994.).

\section{CONCLUSION}

Pasture meat had a higher percentage of PUFAs than that supplemented with FHM or SBM. The pasture meat can be considered healthier than SBM or FHM supplementation in meat due to the higher concentration of desirable fatty acids and lower lipid oxidation.

\section{BIOETHICS AND BIOSSECURITY COMMITTEE APPROVAL}

Protocols and animal handling throughout this experiment were approved by the Committee of Ethics of the Universidad Autonoma del Estado de México. 


\section{ACKNOWLEDGMENTS}

Also, we thank Ms. Penelope Krumm for the critical review of this paper. This project was supported by ICAMEX15-2005-1186, Grupo Produce Estado de Mexico project 197 and UAEM project 2200/2005 and 2204/2005 E. Mr Jose Romero was supported by CONACYT fellowship for his doctoral studies.

\section{REFERENCES}

AOAC (ASSOCIATION OF OFFICIAL ANALYTICAL CHEMISTS). Official methods of analysis. 15.ed. Washington: AOAC INTERNATIONAL, D.C, 1990. 1298p.

AOAC (AOAC INTERNATIONAL). Official Methods of Analysis. 17.ed. Gaithersburg, MD: AOAC international, 2000. 2200p.

BEAULIEU, A.D. et al. Concentrations of conjugated linoleic acid (cis-9, trans-11-octadecadienoic acid) are not increased in tissue lipids of cattle fed a high-concentrate diet supplemented with soybean oil. Journal of Animal Science, v.80, n.3, p.847-861, 2002. Available from: <http://doi.org/10.2527/2002.803847x>. Accessed: Jan. 06, 2016. doi: 10.2527/2002.803847x.

BEZERRA, L.S. et al. Meat quality of lambs fed diets with peanut cake. Meat Science, v.121, p.88-95, 2016. Available from: $<$ http:// doi.org/10.1016/j.meatsci.2016.05.019>. Accessed: May 27, 2016.

DEMIREL, G. et al. Conjugated linoleic acid content of the lamb muscle and liver fed different supplements. Small Ruminant Research, v.53, n.1, p.23-28, 2004. Available from: <http://doi. org/10.1016/j.smallrumres.2003.07.006>. Accessed: Feb. 03, 2016. doi: 10.1016/j.smallrumres.2003.07.006.

ENGLE, T.E. et al. Effects of soybean oil and dietary copper on ruminal and tissue lipid metabolism in finishing steers. Journal of Animal Science, v.78, n.10, p.2713-2721, 2000. Available from: $<$ http://doi.org/10.2527/2000.78102713x>. Accessed: Mar. 09, 2016.

FRENCH, P .et al. Fatty acid composition of intra-muscular triacylglycerols of steers fed autumn grass and concentrates. Livestock Production Science, v.81, n.2-3, p.307-317, 2003. Available from: <http://doi.org/10.1016/S0301-6226(02)002531>. Accessed: Jun. 07, 2016.

GEORGE, D.; MALLERY, P. SPSS for Windows step by step: a simple guide and reference 10.0 update. Toronto: Allyn and Bacon, Toronto. 2001. 371p.

GRUNERT, K.G. et al. Consumer perception of meat quality and implications for product development in the meat sector-A review. Meat Science, v.66 n.2, p.259-272, 2004. Available from: <http://doi. org/10.1016/S0309-1740(03)00130-X>. Accessed: Jan. 18, 2016.

HAJJI, H. et al. Meat physicochemical properties, fatty acid profile, lipid oxidation and sensory characteristics from three North African lamb breeds, as influenced by concentrate or pasture finishing diets. Journal of Food Composition and Analysis, v.48, p.102-110, 2016. Available from: < http://doi.org/10.1016/j. jfca.2016.02.011>. Accessed: Apr. 27, 2016.

HMSO, U. Nutritional aspects of cardiovascular disease (report on health and social subjects No. 46). London: HMSO, 1994. 186p.
KARACA, S. et al. The effect of feeding system on slaughtercarcass characteristics, meat quality, and fatty acid composition of lambs. Archives Animal Breeding, v.59, n.1, p.121-129. 2016. Available from: <http://doi.org/10.5194/aab-59-121-2016>. Accessed: Jul. 05, 2016.

MOLONEY, A.P. et al. Producing tender and flavoursome beef with enhanced nutritional characteristics. Proceedings of the Nutrition Society, v.60, n.2, p.221-229, 2001. Available from: $<$ http://dx.doi.org/10.1079/PNS200077>. Accessed: Oct. 20, 2015.

MORRISON, W.R.; SMITH, L.M. Preparation of fatty acid methyl esters and dimethylacetals from lipids with boron fluoridemethanol. Journal of Lipid Research, v.5, n.4, p.600-608, 1964. Available from: <http://www.jlr.org/content/5/4/600.full. pdf + html $>$. Accessed: Dec. 10, 2015.

PARK, Y. Conjugated linoleic acid (CLA): Good or bad trans fat? Journal of Food Composition and Analysis, v.22, Suppl., p.S4-S12, 2009. Available from: <http://dx.doi.org/10.1016/j. jfca.2008.12.002>. Accessed: Jan. 25, 2016.

PONNAMPALAM, E.N. et al. Effect of diets containing n-3 fatty acids on muscle long-chain n-3 fatty acid content in lambs fed low-and medium-quality roughage diets. Journal of Animal Science, v.79, n.3, p.698-706, 2001. Available from: $<$ http://dx.doi. org/10.2527/2001.793698x>. Accessed: Sept. 18, 2015.

RADUNZ, A.E. et al. Effects of dietary polyunsaturated fatty acid supplementation on fatty acid composition in muscle and subcutaneous adipose tissue of lambs1. Journal of Animal Science, v.87, n.12, p.4082-4091, 2009. Available from: <http://dx.doi.org/10.2527/jas.2009-2059>. Accessed: Jul. 06, 2015.

SERRANO, E. et al. Traceability of grass-feeding in young beef using carotenoid pigments in plasma and adipose tissue. Animal Science, v.82, n.6, p.909-918. 2006. Available from: <http://dx.doi. org/10.1017/ASC200698>. Accessed: Oct. 13, 2015.

STEEL, R.G. et al. Principles and procedures of statistics a biometrical approach. 3.ed. New York: McGraw-Hill, 1997. 672p.

VAN SOEST, P.J. et al. Methods for dietary fiber, neutral detergent fiber, and no starch polysaccharides in relation to animal nutrition. Journal of Dairy Science, v.74, n. 10, p.3583-3597, 1991. Available from: < http://dx.doi.org/10.3168/jds.S0022-0302(91)78551-2>. Accessed: May 02, 2016.

VASTA, V.; PRIOLO, A. Ruminant fat volatiles as affected by diet. A review. Meat Science, v.73, n.2, p.218-228, 2006. Available from: <http://dx.doi.org/10.1016/j.meatsci.2005.11.017>. Accessed: Feb. 17, 2016.

WOOD, J.D. et al. Fat deposition, fatty acid composition and meat quality: a review. Meat Science, v.78, n.4, p.343-358, 2008. Available from: <http://dx.doi.org/10.1016/j.meatsci.2007.07.019. Accessed: Nov. 14, 2015.

ZERVAS, G.; TSIPLAKOU, E. The effect of feeding systems on the characteristics of products from small ruminants. Small Ruminant Research, v.101, n.1-3, p.140-149, 2011. Available from: <http://dx.doi.org/10.1016/j.smallrumres.2011.09.034>. Accessed: Aug. 08, 2015. 